\title{
GREEN SYNTHESIS OF SILVER NANOPARTICLES USING SAGO (METROXYLON SAGU) VIA AUTOCLAVING METHOD
}

\author{
aliYah Jamaludin and Che Ku Mohammad FaizaL * \\ Faculty of Engineering Technology, Universiti Malaysia Pahang, \\ 26300 Gambang, Pahang, Malaysia. \\ *Corresponding author:mfaizal@ump.edu.my \\ (Received: 20 th Feb 2017; Accepted: 29 th Dec 2017; Published on-line: $1^{\text {st }}$ June 2018)
}

https://doi.org/10.31436/iiumej.v19i1.815

\begin{abstract}
Sago (metroxylon sagu) is a polysaccharide bio resource, which is biodegradable and low in toxicity that can be found in large scale in Mukah, Sarawak. A simple green method of synthesizing silver nanoparticles (AgNPs) has been developed using sago dissolved in water as the reducing agent. The mixture of dissolved sago and silver nitrate $\left(\mathrm{AgNO}_{3}\right)$ were autoclaved at $121{ }^{\circ} \mathrm{C}$ for 20 minutes. The size, morphology and structures of the AgNPs formed in the sago solution were investigated through UVVis spectrophotemeter, XRD and FESEM analysis. The synthesized AgNPs were spherical in shape and well distributed with average particle sizes of $19.3 \pm 2.7 \mathrm{~nm}$.
\end{abstract}

ABSTRAK: Sago (Pokok Rumbia) adalah sumber bio polisakarida yang bioterurai dan rendah ketoksikan yang boleh didapati dalam skala yang besar di Mukah, Sarawak. Satu kaedah hijau yang mudah untuk mensintesis nanopartikel perak telah dihasilkan dengan menggunakan sagu yang larut dalam air sebagai ejen penurunan. Campuran sagu yang dilarutkan dan perak nitrat $\left(\mathrm{AgNO}_{3}\right)$ telah autoklaf pada suhu $121^{\circ} \mathrm{C}$ selama 20 minit. Saiz, morfologi dan struktur nanopartikel perak yang terhasil di dalam larutan sago telah disiasat melalui analisis spektrofotometer UV-Vis, XRD dan FESEM. Nanopartikel perak yang dihasilkan adalah berbentuk bulat dengan purata saiz partikel $19.3 \pm 2.7 \mathrm{~nm}$.

KEY WORDS: green synthesis; silver nanoparticles; antibacterial; autoclaving; sago

\section{INTRODUCTION}

Global problem associated with environmental concerns have resulted in wide approach of 'green' method in most of activities worldwide. This awareness involves in most industries and have attracted many researches to work on 'green' materials and methods applicable in varied of applications. One of the most critical field to be concerned about the manufacturing process is the medical field. Therefore, researches are working and innovating the method and process in manufacturing the devices to be applied in biomedical-related field. Some of the key issues that need to be focused is the utilization of nontoxic chemicals, environmentally benign solvents and renewable materials ${ }^{[1-2]}$. One of those field is the process of synthesizing nanoparticles to be applied as the antibacterial agent in medical application. Silver nanoparticles (AgNPs) field of research has become the as the focus attention among other metal nanoparticles such as copper, zinc, titanium, magnesium and gold [3]. The applications of AgNPs involved in renewable energies, water treatment, cosmetics and biomedical devices [4]. One of the best properties of AgNPs is the antibacterial efficacy against bacteria, viruses and some other micro-organisms [5]. Since 
decades ago, AgNPs have been applied as antibacterial agents in health industry, food storage, textile coatings and number of environmental applications [6].

Generally, AgNPs can be synthesized through several methods such as chemical, physical, photochemical and biological synthesis. Among those methods, chemical synthesis via chemical reduction method is the most frequently applied for the preparation of AgNPs in water or organic solvent. The silver ions $\left(\mathrm{Ag}^{+}\right)$are reduced by the reducing agents such as borohydride, citrate and ascorbate. However, most of these reducing agents are highly reactive and non-environmetally friendly components [7]. Therefore, the alternative synthesis routes have been developed through green methods to prepare AgNPs. Green synthesis method is simpler and will minimize or eliminate the toxic waste. The preparation of AgNPs via green synthesis should be evaluated from the choices of the medium, no-toxic reducing agent and stabilizer material. Generally, water is used as the environmental friendly solvent. Meanwhile, glucose is widely used as a green reducing agent becuase of its chemical reaction rate which allows a compromise between the nuclei created and the growth of the AgNPs ${ }^{[8-9]}$. Further, polysaccharide such as starch, chitosan and gums are used as the stabilizer in the preparation of AgNPs $[4,10]$. In some cases, polysaccharides serve as the reducing agent, capping agent and stabilizer.

Sago is a starch, a type of natural polymer available in nature. In Malaysia, large scale commercial sago plantations are found in Mukah, Sarawak and Beaufort, Sabah. Sago or scientifically named as Metroxylon sago is a white, tasteless, and odourless natural polymer extracted from the pith of sago palm stems. The extracted sago is manufactured into powder or "pearl" form. Currently, sago industry became one of the country's important agricultural export commodities [11]. Sago is traditionally cooked and eaten in various forms. It is also used commercially in making noodles and bread. However, the use of sago is not just limited to the food industry. Sago is also used as a key material input in various industries, such as in the paper, plywood, and textile industries [12]. Similar to other kind of starch, sago is also categorized as polysaccharides which consist of aldehyde groups. The presence of hydroxyl will facilitate the complexation of silver ions by electrostatic binding in the helical structure of polysaccharide [13-14]. Therefore, these silver ions oxidize the hydroxyl groups to carbonyl groups, during which the silver ions are reduced to elemental silver as shown in Equation (1) below.

$$
\operatorname{AgNO}_{3}(a q)+R C H O(a q)=A g(s)+R C O O H(a q)
$$

Therefore, sago is a great candidate to be utilize as the reducing agent to synthesize AgNPs. Thus, the aim of this work is to eliminate the toxic waste by using sago as the reducing agent and also to simplify the method of synthesizing AgNPs via autoclaving method which is simple and quick.

\section{MATERIAL AND METHODS}

Silver nitrate $\left(\mathrm{AgNO}_{3}\right.$, Sigma-Aldrich) of analytical reagent grade was used for the synthesis. Sago powder was purchased from Dhulau Enterprise, Putatan, Sabah, Malaysia. The materials were used without purification. All the solutions were prepared in deionized water. Sago solutions were prepared by adding 0.4, 0.8, 1.2, 1.6 and 2.0 volume/weight percentage $(\mathrm{w} / \mathrm{v} \%)$ of Sago powder into $50 \mathrm{ml}$ deionized water. Then, the sago solutions were mixed with $1 \mathrm{mM}$ of $\mathrm{AgNO}_{3}$ solution with mixture ratio of $1: 1.5$. The mixtures were autoclaved at $121{ }^{\circ} \mathrm{C}$ for 20 minutes to synthesize the AgNPs. The autoclave used in this work is as shown in Figure 1. Then, the AgNPs solution were characterized through UV- 
visible spectrometer within the wavelenght range of $400-800 \mathrm{~nm}$ to monitor the surface plasmon resonance. X-Ray Diffraction (XRD) analysis was carried out in $2 \theta$ range of 30 $80^{\circ}$ to confirm the crystal structure of the AgNPs. Further, the size and morphology of the

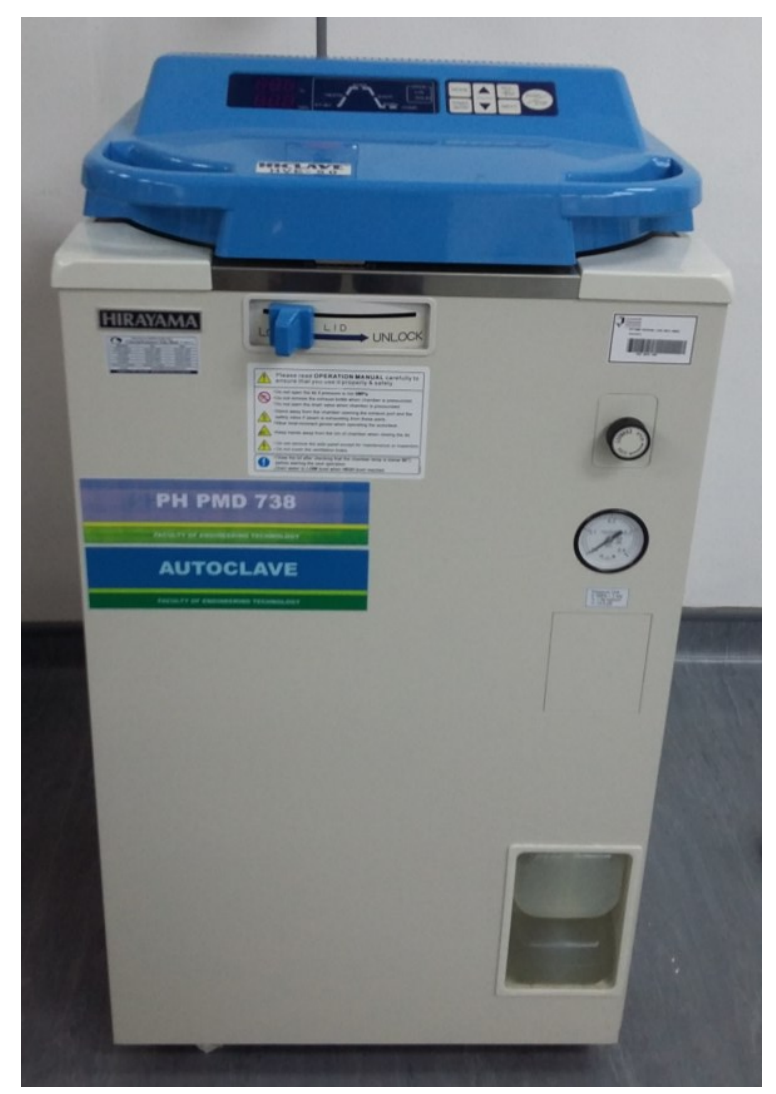

synthesized AgNPs were also characterized through Field Emission Scanning Electron Microscope (FESEM).

Fig. 1: Autoclave machine used to synthesize AgNPs at $121^{\circ} \mathrm{C}$ for 20 minutes.

\section{RESULTS AND DISCUSSION}

\subsection{UV-Visible spectroscopy (UV-Vis) Analysis}

The presence of nanoparticles in liquid is commonly observed by using UV-Vis spectroscopy. It is a sensitive and quick technique to confirm the formation of AgNPs by monitoring the absorption spectra and the wavelength. The range of wavelength for AgNPs must be in between 400-450 nm. Physically, the colour changes of the AgNPs solution also indicated the formation of AgNPs. Figure 2 (a) shows the absorption spectra of AgNPs solution with varies Sago concentrations synthesized via autoclaving at $121{ }^{\circ} \mathrm{C}$ for 20 minutes. Each of the solution exhibits absorption peak in the range of nanoparticles wavelength which are 411, 410, 408, 410 and $413 \mathrm{~nm}$ with increasing percentage of Sago from $0.4-2.0(\mathrm{w} / \mathrm{v}) \%$. However, only AgNPs solution with $1.2(\mathrm{w} / \mathrm{v}) \%$ of Sago concentration did not show any peak around $330 \mathrm{~nm}$ as shown in the highlighted area in the figure. This result indicated that there were no aggregations of particles within the solution. Figure 2 (b) shows a clearer view of the absorption and the wavelength of the AgNPs solution. The absorption of AgNPs solution showed a direct proportional increment to the concentration of Sago. The higher the absorption is referred to the higher amount of AgNPs that have been formed. Further, the wavelength is referred to the size of the AgNPs. Larger AgNPs tend to agglomerate to minimize their higher surface energy. When AgNPs 
aggregate and the conduction electrons near each particle surface become delocalized and are shared amongst neighbouring particles. Hence, the surface plasmon resonance shifts to lower energies, causing the absorption peaks shift to longer wavelengths. From the figure, AgNPs solution with $1.2(\mathrm{w} / \mathrm{v}) \%$ Sago concentrations show the lowest wavelength at 408 $\mathrm{nm}$ which indicate the formation of smaller size AgNPs. Physically, the colour changes of the AgNPs solution from translucent to light yellow as shown in Figure 2 (c) also proved the formation of AgNPs. The colour changes may be due to the excitation of surface Plasmon resonance and reduction of $\mathrm{AgNO}_{3}$ [15].From this UV-Vis analysis, it is proved that the aldehyde groups from sago have reduced the silver ions, to the elemantel silver [14]. The basic reduction mechanisme of silver ions by aldehyde group to elemantel silver is shown in Equation (1).

(a)

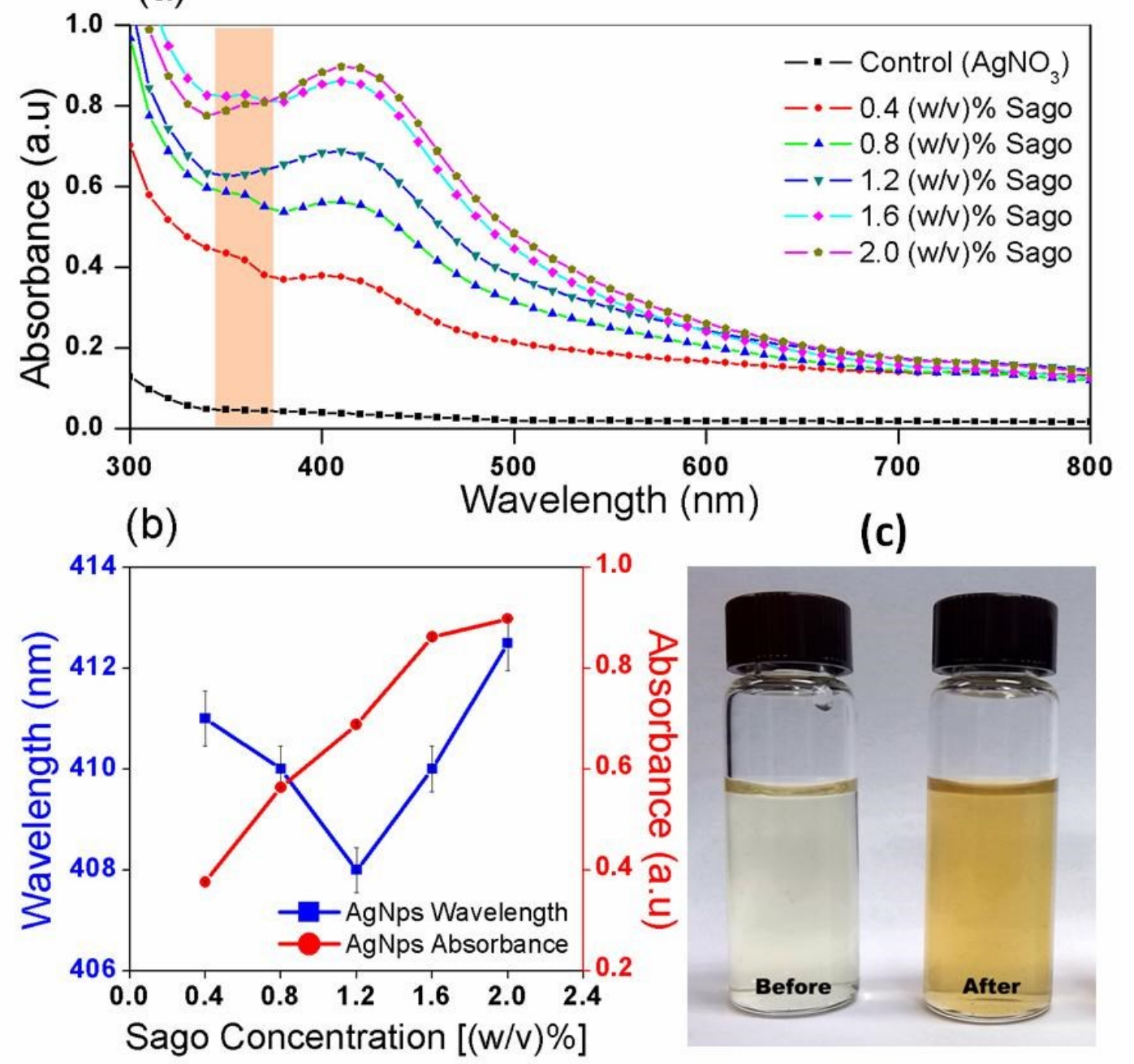

Fig. 2: (a) The UV-Vis absorption spectra of the synthesized AgNPs with varies Sago concentration (b) Wavelength and absorbance of AgNPs with varies Sago concentration (c) The colour changes of the mixture before and after autoclaving process.

\subsection{X-Ray Diffraction(XRD) Analysis}

The crystal structure of the synthesized AgNPs were confirmed through XRD analysis. Figure 3 shows the XRD pattern of the synthesized AgNPs with 1.2 (w/v) \% of Sago. The 
XRD spectrum shows the $2 \theta$ degree peaks at $38.38,44.52,64.72$ and 77.83 corresponding to (111), (200), (220) and (311), respectively. Peak (111) is more intense than the other planes which show broadening pattern because of the size of nanoparticles and the presence of premature Ag lattice plane [16,17]. Peak broadening is normally seen in crystallites smaller than $100 \mathrm{~nm}$. Nano particles have much less atoms hence the lattice sum is not able to converge to a diffraction line but broaden out. This condition complies with the terms of the Scherrer equation where peak width is inversely proportional to crystallite size. The same XRD peaks of AgNPS synthesized using other starches have also been reported by Hebeish et al. And Ghaseminezhad et al. [18-19].

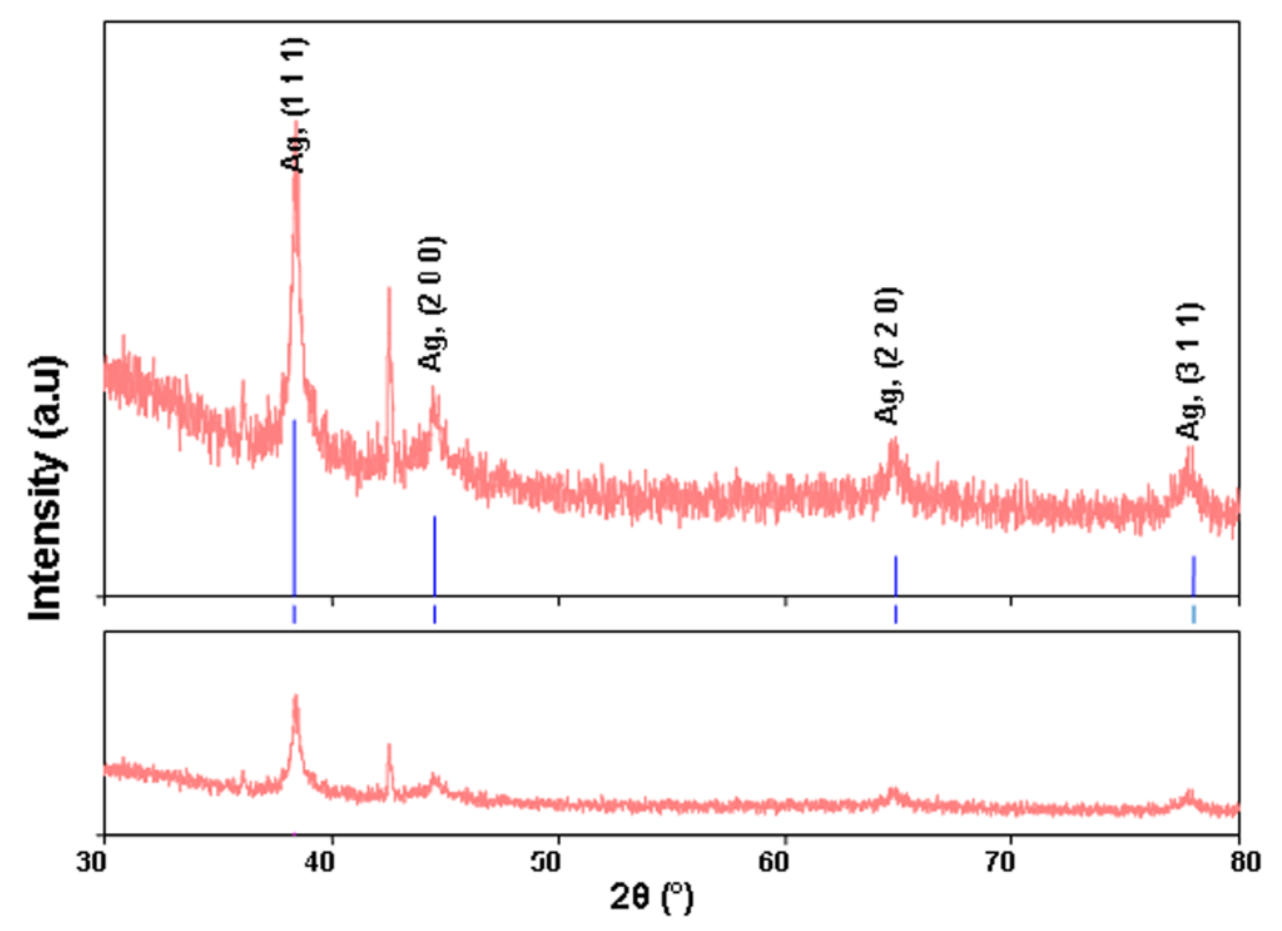

Fig. 3: XRD pattern of the synthesized AGNPs using $1.2(\mathrm{w} / \mathrm{v}) \%$ Sago.

\subsection{Field Emission Scanning Electron Microscope (FESEM) Analysis}

FESEM images of the synthesized AgNPs are shown in Figure 4 at different magnifications of 50000 and 150000 times, respectively. Both Figure 4 (a) and (b) reveal that the AgNPs are well dispersed and spherical in shape. The average particle size of the AgNPs is $19.3 \pm 2.7 \mathrm{~nm}$, calculated using ImageJ software. The size of these green synthesized AgNPs are comparable to the AgNPs that used PVA, a synthetic polymer as the reducing agent produced by Sagitha and coworkers [20].

\section{CONCLUSION}

This work reports the green synthesis of $\mathrm{AgNPs}$ from $\mathrm{AgNO}_{3}$ using Sago as the reducing agent. We have demostrated a simple, efficient, quick and green technique to produce AgNPs via autoclaving method. All the analysis through UV-Vis, XRD and FESEM have recorded comparable and promising results as other AgNPs synthesized using other methods. The size, morphological and particle distribution of these green synthesized AgNPs also proved that Sago acts as a good reducing agent as other synthetic polymers. 

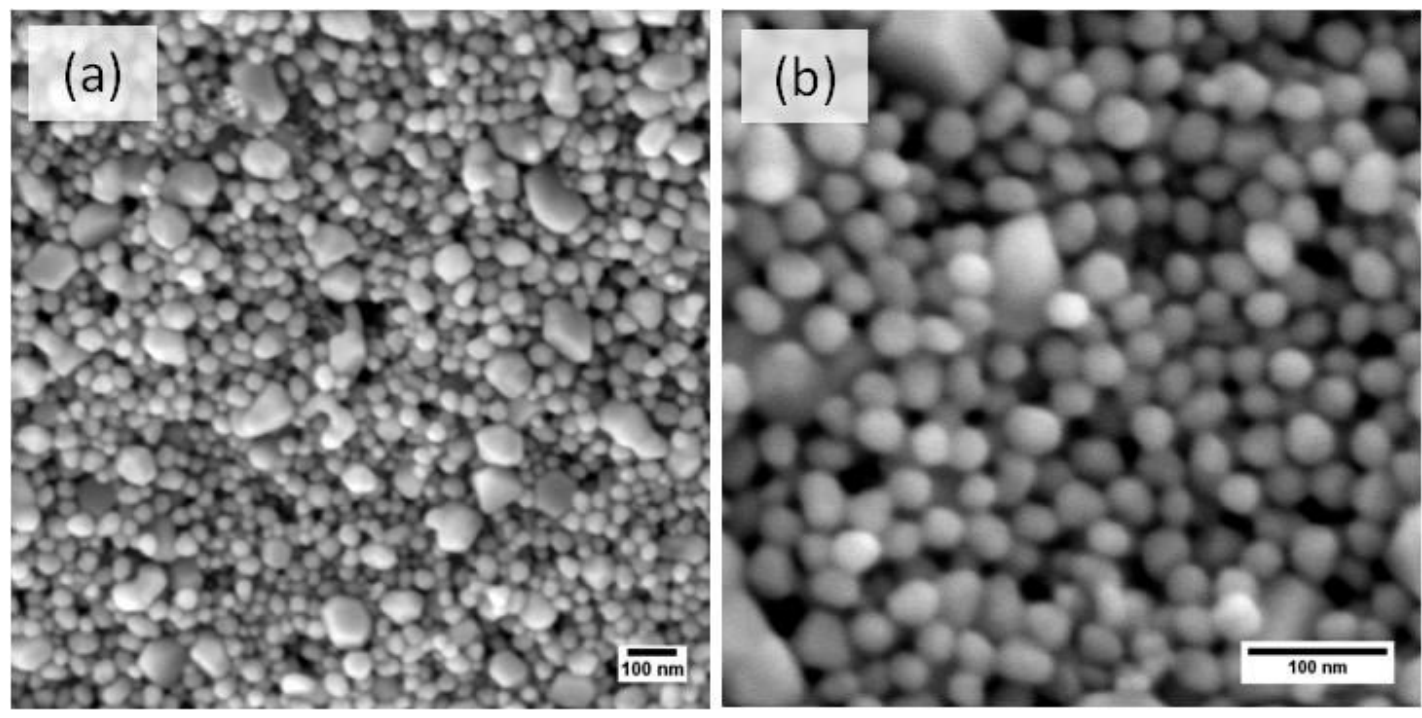

Fig. 4: FESEM images of the synthesized AgNPs with different maginifications (a) $50000 \mathrm{x}$ and (b) $150000 \mathrm{x}$.

\section{ACKNOWLEDGEMENT}

The authors would like to thank Universiti Malaysia Pahang for the financial assistance under the grant of RDU140346.

\section{REFERENCES}

[1] Fei X, Jia M, Du X, Yang Y, Zhang R, Shao Z, Zhao X, Chen X. (2013) Green synthesis of silk fibroin-silver nanoparticle composites with effective antibacterial and biofilm-disrupting properties. Biomacromolecules, 14:4483-4488.

[2] Raveendran P, Fu J, Wallen SL. (2003) Completely 'Green' Synthesis and Stabilization of Metal Nanoparticles. Journal of the American Chemical Society, 125:13940-13941.

[3] Moritz M, Geszke-Moritz M. (2013) The newest achievements in synthesis, immobilization and practical applications of antibacterial nanoparticles. Chemical Engineering Journal, 228:596-613.

[4] Vigneshwaran N, Nachane RP, Balasubramanya RH, Varadarajan P V. (2006) A novel one-pot 'green' synthesis of stable silver nanoparticles using soluble starch. Carbohydrate Research, 341:2012-8.

[5] Venkatpurwar V, Pokharkar V. (2011) Green synthesis of silver nanoparticles using marine polysaccharide: Study of in-vitro antibacterial activity. Materials Letters, 65:999-1002.

[6] Abou El-Nour KMM, Eftaiha A, Al-Warthan A, Ammar R a. a. (2010) Synthesis and applications of silver nanoparticles. Arabian Journal of Chemistry, 3:135-140.

[7] Cheviron P, Gouanvé F, Espuche E. (2014) Green synthesis of colloid silver nanoparticles and resulting biodegradable starch/silver nanocomposites. Carbohydrate Polymers, 108:291-298.

[8] Vasileva P, Donkova B, Karadjova I, Dushkin C. (2011) Synthesis of starchstabilized silver nanoparticles and their application as a surface plasmon resonancebased sensor of hydrogen peroxide. Colloids and Surfaces A: Physicochemical and Engineering Aspects, 382:203-210. 
[9] Singh M, Sinha I, Mandal RK. (2009) Role of pH in the green synthesis of silver nanoparticles. Materials Letters, 63:425-427.

[10] Xu W, Jin W, Lin L, Zhang C, Li Z, Li Y, Song R, Li B. (2014) Green synthesis of xanthan conformation-based silver nanoparticles: antibacterial and catalytic application. Carbohydrate Polymers, 101:961-7.

[11] Karim AA, Nadiha MZ, Chen FK, Phuah YP, Chui YM, Fazilah A. (2008) Pasting and retrogradation properties of alkali-treated sago (Metroxylon sagu) starch. Food Hydrocolloids, 22:1044-1053.

[12] Abd-Aziz S. (2002) Sago starch and its utilisation. Journal of Bioscience and Bioengineering, 94:526-529.

[13] Gao X, Wei L, Yan H, Xu B. (2011) Green synthesis and characteristic of core-shell structure silver/starch nanoparticles. Materials Letters, 65:2963-2965.

[14] Kora AJ, Beedu SR, Jayaraman A. (2012) Size-controlled green synthesis of silver nanoparticles mediated by gum ghatti (Anogeissus latifolia) and its biological activity. Organic and Medicinal Chemistry Letters, 2:17.

[15] Ahmed S, Ahmad M, Swami BL, Ikram S. (2014) A review on plants extract mediated synthesis of silver nanoparticles for antimicrobial applications: A green expertise. Journal of Advanced Research, 7:17-28.

[16] Venkatesham M, Ayodhya D, Madhusudhan A, Veera Babu N, Veerabhadram G. (2012) A novel green one-step synthesis of silver nanoparticles using chitosan: catalytic activity and antimicrobial studies. Applied Nanoscience, 4:113-119.

[17] Zheng Y, Zhu Y, Tian G, Wang A. (2015) In situ generation of silver nanoparticles within crosslinked 3D guar gum networks for catalytic reduction. International Journal of Biological Macromolecules, 73:39-44.

[18] Hebeish A, El-Rafie MH, El-Sheikh MA, El-Naggar ME. (2013) Nanostructural features of silver nanoparticles powder synthesized through concurrent formation of the nanosized particles of both starch and silver. Journal of Nanotechnology, 2013:110 .

[19] Ghaseminezhad SM, Hamedi S, Shojaosadati SA. (2012) Green synthesis of silver nanoparticles by a novel method: comparative study of their properties. Carbohydrate Polymers, 89:467-72.

[20] Sagitha P, Sarada K, Muraleedharan K. (2016) One-pot synthesis of poly vinyl alcohol (PVA) supported silver nanoparticles and its efficiency in catalytic reduction of methylene blue. Trans Nonferrous Met Soc China, 26:2693-2700. 